\title{
Novel analytical technologies of Quality in the Sheep \& Goat Dairy Sector
}

\author{
Psathas $\mathrm{G}^{*}$ and Tzamaloukas $\mathrm{O}$
}

\author{
Department of Biological Sciences - Technological University Limassol, Cyprus
}

${ }^{*}$ Corresponding author: Psathas G, Department of Biological Sciences - Technological University Limassol, Cyprus, E-mail: gpsathas@cytanet.com.cy

Citation: Psathas G, Tzamaloukas O (2017) Novel analytical technologies of Quality in the Sheep \& Goat Dairy Sector. J Vet Sci Ani Husb 5(2): 205. doi: 10.15744/2348-9790.5.205

Received Date: March 28, 2017 Accepted Date: May 23, 2017 Published Date: May 25, 2017

\begin{abstract}
France, Greece, Italy, and Spain the major sheep and goat milk producers in Europe, got the initiative through an interim of 30 years (1985 - 2015), to organize - through IDF - 7 symposiums aiming at the upgrade of the Dairy Sector. One major interest was the milk quality. Stepwise, the efforts followed cow milk structural development in organizing the testing laboratory, the definition of quality in composition (fat, protein, lactose, total solids), in Hygienic (Total Bacteria Count, Somatic Cell Count, antibiotics residues and Aflatoxin M1 contamination), adulteration with water and detection of milk species. EU, by Decision 2002/657/EC, defined the rules for the Directive 96/23/EC, enumerated the testing methods, the demands in sampling procedures, the minimum limits of performance, the quality control (ISO 17025) and the interpretation of results. The equivalency of results from different laboratories, through ISO 17025 , demanded the application of ISO analytical standards. In a period of 5 years these standards have been reformed in order to cover the needs of sheep and goat milk analysis. Novel development in analytical instrumental methods, like FTIR interferometer working with mid-Infrared region of the spectrum from $3-10 \mu \mathrm{m}$ corresponding to $1000-5000 \mathrm{~cm}-1$, gives opportunities of collecting data by making measurements for new parameters in complex dairy products, like Urea in milk, FFA profile, casein, pH, etc. Flow Cytometry for Individual Bacteria Count and Somatic Cells Count is opening the road for applications on testing for raw milk in hygienic control of the sheep and goat dairy sector. New developed screening methods are applied to give rapid results for antibiotics or aflatoxin M1 residues. Milk quality in the Central Testing Laboratory of today, is upgraded and promoted through rapid, trustful and traceable systems of LIMS in payments and herd management. Milk species mixtures can today be analysed in milk and dairy products with screening and reference methods. PDO products need today testıng methods for authenticity of animals' breed and geographical region of production.
\end{abstract}

Keywords: Sheep and goat dairy sector; Milk quality; Testing lab; Novel technology

List of Abbreviations: EU: European Union; EAAP: European Association of Animal Protection; IDF: International Dairy federation; ISO: International Standards Organization; FTIR: Fourier Transformation Infrared; TLC: Thin Layer Chromatography; GLC: Gas Liquid Chromatography; HPLC: High Pressure Liquid Chromatography; RP HPLC: Reverse Phase High Pressure Liquid Chromatography; PAGE: Polyacrylamide Gel Electrophoresis; IEF: Isofocus Electrophoresis; CZE: Capillary Zone Electrophoresis; SOPs: Standard Operation Procedures; WP: Whey Proteins; C: Casein; RFID: Radio Frequency Identification; GSM: Global System for Mobile

\section{Introduction}

Sheep and goat dairy products have interesting characteristics in their levels of flavor, taste, aromas and leanness as well as the specific composition of fats, proteins, amino and fatty acids. Their quality is very much linked to historical and cultural uniqueness right through the production, marketing and consumption chains. Despite the superiority of their characteristics, they represent only $4 \%$ of total world production. More than $50 \%$ of this production is produced in Mediterranean basin. Four countries, Greece, Italy, Spain and France are the main contributors in Europe which by addition of Turkey, in Mediterranean basin, represent 58\% worldwide. This extensive production refers to farming systems with dominant extensive grazing situations, specific technologies and conditions for the transformation processes of cheese-making and its ripening; The products are characterized by traditional nutritional habits of the consumers. While their organoleptic properties are very important, the sanitary aspects become more and more influential and tend to modify the accepted definitions of these products and their quality (e.g. non-pasteurized milk, production chains, hygiene, transformation methodologies, etc.). In a rapidly changing world the sustainability of the Sector became a major issue. New technologies through research and development were required to monitor the products in a better position of the international dairy food market. The upgrading of the sector became an utmost necessity and challenge for the interested parties. 


\section{The Forum of Sheep and Goat Dairy Sector}

An initiative of Greece - with warm embrace from France, Italy and Spain on 1985-, started for sheep \& goat dairy sector under IDF with ICAR, EAAP, CIRVAL, EDA and CIEAM. This initiative created a Forum which in an interim of 30 years - up to 2015 - produced about 800 scientific works, with important messages in the major fields of the sector Raw Material, Processing and Product, Products Characteristics, and Marketing Strategies.

Since Quality was a dominating issue in all above fields, analytical testing became an utmost necessity as a tool to reveal the advantages below of these milk species.

$\Delta$ Revelation of Fatty acids Superior Biological Value in Human Nutrition

$\checkmark$ Proteins polymorphism and the connection to milk production and cheese yield

$\checkmark$ Genetic character of lactic acid bacteria in fermented products - probiotics and bacteriocins production

At the same time, the Forum in the process of the 7 symposiums disclosed the major key trends governing the sector industry [1]:

D The milk production system cannot survive without governmental support. This support should aim to farm reformation and producers' education. A further development in breeding control, milk collection and farmers' payment based on quality schemes is required.

$\checkmark$ To this effort, we should account the issues of animal health and nutrition and the environmental impact, bearing in mind the numbers of more than one billion of dairy sheep and 600 million of dairy goats.

$\checkmark$ On the other hand, we cannot ignore the demand of consumers for better quality (flavor, texture, natural ingredients), better biological value and or organic products.

$\Delta$ Finally, food safety away from animal diseases, microbial contaminations, residues of antibiotics and aflatoxins.

\section{The Milk Central Testing Laboratory (CT Lab)}

Organizing the process from Research to Development three major partners is involved: Producers, Processors and the CTLAB. Quality is playing a significant role. This role is revealed and described in detail only by CTLAB. The contribution of CTLAB is focused in 3 major missions:

$\checkmark$ Massive analytical data for several parameters for the schemes of payments to producers

$\checkmark$ Milk recording activities - Herd management (Nutrition, breeding control)

$\checkmark$ Safety controls as demanded by EU REG. 853/2004 for milk hygiene

The principle of organizing the CTLAB is the production of massive data with highly organized controls with automation in sampling, samples registration, automatic analysis, automatic handling of analytical data and rapid briefing of interested customers either producers or processors.

Novel technologies of today are providing solutions to fulfill the below characteristics of the modern CT Lab:

$\checkmark$ Massive number of samples

$\checkmark$ Automatic sampling procedures by road tankers during milk collection and delivery to processors

$\checkmark$ Automatic detection of producers and processors and capture of sampling data by the use of GPS and GSM systems

$\checkmark$ Use of RFID system for milk recording in Herd management

$\checkmark$ Automatic sample registration and preparation of batches for analysis

$\checkmark$ Use of automatic instruments for analysis

$\checkmark$ Handle of analytical data produced by the use of Laboratory Information Management System (LIMS)

$\checkmark$ Rapid final results up to $48 \mathrm{hrs}$ and interested customers briefing through Internet or cellular phone

\section{Quality system and quality assurance in the Lab}

For a trustful laboratory, it is necessary to provide evidence of its proficiency in providing validated analytical data. This can be succeeded by organized steps in quality assurance for its work. The basic characteristics are listed below:

$\Delta$ Methods selection (Decision 2002/657/EC)

$\checkmark$ Novel technology equipment with protocols for standard operation, performance controls and maintenance

$\checkmark$ Methods validation

$\checkmark$ Standard Operating Procedures - SOPs

$\triangle$ Quality Manual

$\triangleright$ Controls (Standard samples, control charts)

$\checkmark$ Proficiency testing

$\checkmark$ Documentation

$\checkmark$ Accreditation (17025) 


\section{Analytical methods}

The testing methods for milk composition, during the decade of '70, were semiautomatic nephelometry for fat, amidoblack chromatometric for protein and oxidation iodometric chloramine $\mathrm{T}$ for lactose. In the next decade, the new generation turn to Infrared Spectroscopy with automatic modes of MidIR filters technique giving the chance in one test to get results for fat, protein, lactose and total solids. In '90s, there was a further development in analysis, technology with models based on FTIR (Fourier Transformation Infrared Medium Spectrum\}. This development opened the door to make measures in an area equivalent to 700 filters which means that in Medium Spectrum through calibration from a reference method with calibration procedures, somebody could create new parameters, like pH, FFA, Casein, Urea, Furosine, etc. Since every parameter needs a reference method, an ISO standard needed to follow in order to calibrate the routine instrument. Until 2004, nobody put in doubt these ISO standards whose collaborative studies were based only on cow milk which means that errors were incorporated in analysis of sheep and goat milk. The following methods were reconsidered through new collaborative studies and adopted with annexes for sheep and goat milk precision figures in a period of 5 years:

$\checkmark$ Fat in milk: - Rose Gottlieb (FIL/IDF 1D) - Reference method

$\triangleright$ Nitrogen in milk - Kjeldahl (FIL/IDF 20B: 1993) - Reference method

$\Delta$ Freezing Point in milk (FIL/IDF 108:2001) - Reference method

$\checkmark$ Urea in milk (FIL/IDF- ISO 14637 Draft) - Reference method

$\checkmark$ Somatic cells count in milk (FIL/IDF 148A: 1995) - Reference method

$\checkmark$ Microbial inhibitor tests in milk (ISO 13969/IDF 183 Draft)

$\rightarrow$ Determination of Fat, Protein and Lactose content in milk (FIL/IDF 141A:1990- Mid IR guidance) -Routine method

$\checkmark$ Milk - Quantitative determination of bacteriological quality - Guidance on evaluation of routine methods (FIL/IDF 161B)

\section{Application of novel technology in milk composition by Infrared Spectroscopy}

IR spectrum technology is based on the Lambert Beer law:

$$
A=\mathrm{e} I \mathrm{c}=\log \mathrm{I}_{0} / \mathrm{I}
$$

Where A: absorbance, e: coefficient of molar absorptivity, I: cuvette length, c: molar concentration of analytical parameter, lo: Intension of falling beam, 1 : intension of beam after absorbance

With the previous Mid IR technique of filters (Figure 1), between the light source and the sample in the cuvette, a filter permits a specific wavelength light to pass through. This light is absorbed by the specific bonds which characterize the fat or the protein or the lactose (Figure 2). Fat has two cases of different filters, the filter A for $\mathrm{C}=\mathrm{O}$ bonds of fatty acids on the triglycerides at $5,7 \mu \mathrm{m}$ wavelength and the filter B for the $\mathrm{C}-\mathrm{H}$ of the main skeleton of triglycerides at 3,5 $\mu \mathrm{m}$ wavelength. Protein measure is based on amides bonds $\mathrm{N}-\mathrm{H}_{2}$ at 6,7 $\mu \mathrm{m}$ wavelength and Lactose on $-\mathrm{OH}$ bonds of lactose ring at 9,5 $\mu \mathrm{m}$ wavelength.
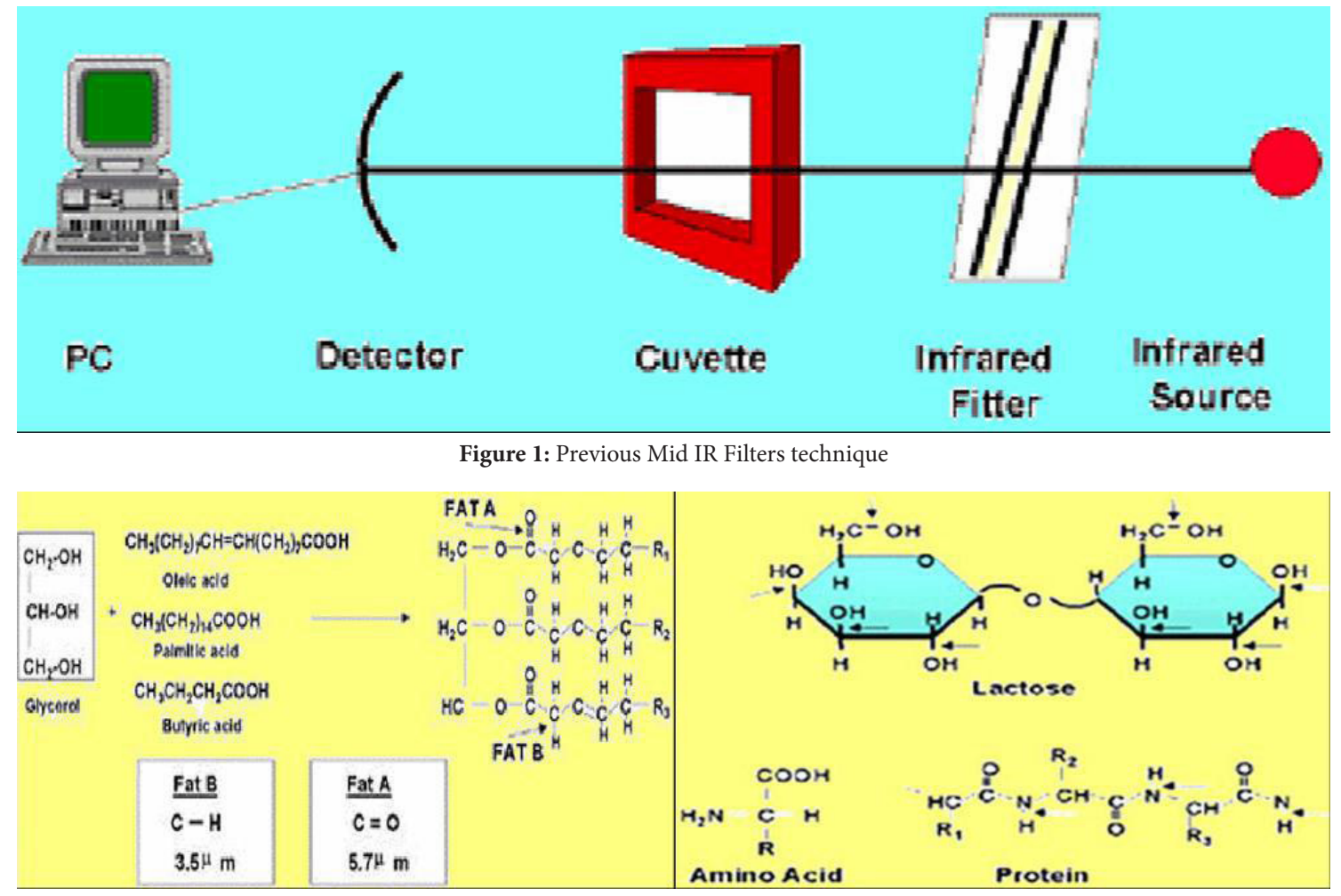

Figure 2: Wavelengths absorbance at specific bonds of fat, protein, lactose 
Novel technology uses Fourier Transformation Infrared Spectroscopy (FTIR).

\section{The infrared optical system}

A built in Interferometer FTIR based on the principle of fixed filters is used in the unit. However, the unit detects the FTIR full infrared range, which can be used in innovative applications. The collection of data from the full range ensures at the same time the flexibility and additional features in the IR analysis.

\section{The basic principles of Interferometry}

Interferometry is a very competitive method compared to traditional techniques. All frequencies from the IR source used without any default, which allows the collection of full- spectrum in time less than a second. This is based on the principle of light contributions (interferences), which shape the range of a signal, as a function of the difference path between two interactive sources. An interferometer captures the intensity of light received from the detector as a function of path difference generated by the displacement of a moving mirror. The small displacement measurement of this mirror is achieved, with the help of a laser beam that follows the same path with a IR radiation. However, at this level, the interferogram refers to the location of the moving mirror and not at the wavelength of interest. The infrared radiation from the source of IRE impinging on sliced-radiation, which reflects half the radiation in a fixed mirror and the other half of the radiation in a mobile mirror. From mirrors, radiation IR reflected and reconnected before reaching the detector. All IR frequencies are transported via interferometer simultaneously, and quick small mirror movements allow simultaneous production of the whole range of IR.

\section{The transformation by Fourier principle}

The principle of transformation in Fourier (FT) is based on the fact, that each function can be divided into a set of sinusoidal functions, where each function sine wave is defined by two values: the frequency (wavelength) and intensity. Fourier transformation is a mathematical process that allows the separation of a fringe effect contribution (interferogram) into a set of sinusoidal functions, each of which represents a given wave. The frequency and intensity of this, is calculated by the data of the interferogram. In a few seconds, the frill contribution (interferogram) collected from the spectrometer, is processed through processing in Fourier transform, and turns into a full spectrum of the sample (Figure 3).

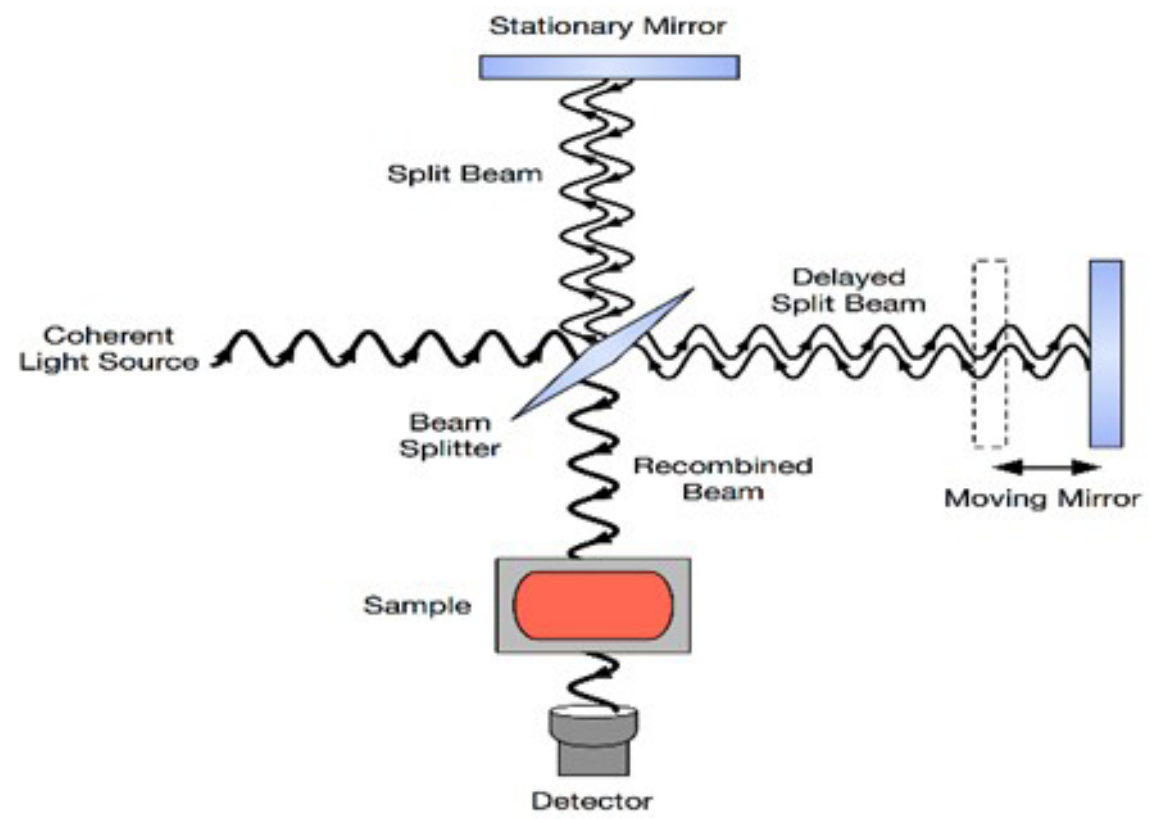

Figure 3: Novel technique of FTIR Interferometer

It is very valuable for the information retrieved. One can see the list of compounds that can be analyzed today (Table 1). Research in sheep and goat has shown superiority of biological value of certain fatty acids (Table 2). This information here is very significant in the hands of nutritionist for the herd management.

\begin{tabular}{|c|c|c|c|c|c|}
\hline Component & $\begin{array}{c}\text { Measuring } \\
\text { range }\end{array}$ & $\begin{array}{c}\text { Performance } \\
\text { range }\end{array}$ & Repeatability & $\begin{array}{c}\text { Accuracy bulk } \\
\text { Accuracy single } \\
\text { animal }\end{array}$ \\
\hline Fat (A) & $\mathbf{0 - 1 5 \%}$ & $\mathbf{2 - 1 5 \%}$ & $\mathbf{C v}<\mathbf{0 , 5} \%$ & $\mathbf{C v}<\mathbf{1 , 0} \%$ & $\mathbf{C v}<\mathbf{1 , 5} \%$ \\
\hline Fat (B) & $0-15 \%$ & $2-15 \%$ & $\mathbf{C v}<\mathbf{0 , 5} \%$ & $\mathrm{CV}<1,0 \%$ & $\mathrm{Cv}<1,5 \%$ \\
\hline Protein & $0-10 \%$ & $2-10 \%$ & $\mathbf{C v}<\mathbf{0 , 5} \%$ & $\mathrm{Cv}<0,9 \%$ & $\mathrm{Cv}<1,5 \%$ \\
\hline
\end{tabular}




\begin{tabular}{|c|c|c|c|c|c|}
\hline Component & $\begin{array}{c}\text { Measuring } \\
\text { range }\end{array}$ & $\begin{array}{c}\text { Performance } \\
\text { range }\end{array}$ & Repeatability & Accuracy bulk & $\begin{array}{c}\text { Accuracy single } \\
\text { animal }\end{array}$ \\
\hline Lactose & $0-10 \%$ & $2-10 \%$ & $\mathbf{C v}<\mathbf{0 , 5} \%$ & $\mathrm{Cv}<0,9 \%$ & $\mathrm{Cv}<1,5 \%$ \\
\hline Solids & $0-20 \%$ & $2-20 \%$ & $\mathbf{C v}<\mathbf{0 , 5} \%$ & $\mathrm{Cv}<1,0 \%$ & $\mathrm{Cv}<1,5 \%$ \\
\hline Urea & $10-100 \mathrm{mg} / \mathrm{dl}$ & $10-100 \mathrm{mg} / \mathrm{dl}$ & $\mathrm{Sd}<1,5 \mathrm{mg} / \mathrm{dl}$ & $\mathrm{Sd}<1,5 \mathrm{mg} / \mathrm{dl}$ & $\mathrm{Sd}<3,5 \mathrm{mg} / \mathrm{dl}$ \\
\hline Citric acid & $0,1-0,5 \%$ & $0,1-0,5 \%$ & $\mathrm{Sd}<0,005 \%$ & $\mathrm{Sd}<0,01 \%$ & $\mathrm{Sd}<0,015 \%$ \\
\hline FPD & $400-600 \mathrm{~m}^{\circ} \mathrm{C}$ & $450-550 \mathrm{~m}^{\circ} \mathrm{C}$ & $\mathrm{Sd}<0,5 \mathrm{~m}^{\circ} \mathrm{C}$ & $\mathrm{Sd}<4 \mathrm{~m}^{\circ} \mathrm{C}$ & $\mathrm{N} / \mathrm{A}$ \\
\hline Component & $\begin{array}{c}\text { Measuring } \\
\text { range }\end{array}$ & $\begin{array}{c}\text { Performance } \\
\text { range }\end{array}$ & & & \\
\hline Casein & $2,17-3,45 \%$ & $2,17-3,24 \%$ & $\mathrm{~N} / \mathrm{A}$ & $\mathrm{N} / \mathrm{A}$ & $\mathrm{N} / \mathrm{A}$ \\
\hline $\begin{array}{c}\mathrm{FFA} \\
\text { mmol/10kg }\end{array}$ & $0,072-10,04$ & $0,49-6,63$ & $\mathrm{~N} / \mathrm{A}$ & $\mathrm{N} / \mathrm{A}$ & $\mathrm{N} / \mathrm{A}$ \\
\hline \multicolumn{2}{|r|}{ Ketosis screening (acetone $>0,15$ mmol/lt, acetoacetic acid and b hydroxybutyric acid $-\mathrm{BHB}>0,1 \mathrm{mmol} / \mathrm{lt}$} \\
\hline
\end{tabular}

Table 1: Basic analytical parameters with FTIR

\begin{tabular}{|c|c|c|}
\hline Component & Calibration range & Validation range \\
\hline Saturated Fatty Acids & $0,87-5,08 \%$ & $0,87-5,08 \%$ \\
\hline $\begin{array}{c}\text { Mono Unsaturated Fatty } \\
\text { Acids }\end{array}$ & $0,31-2,84 \%$ & $0,31-2,84 \%$ \\
\hline $\begin{array}{l}\text { Poly Unsaturated Fatty } \\
\text { Acids }\end{array}$ & $0,03-0,36 \%$ & $0,03-0,36 \%$ \\
\hline Unsaturated Fatty Acids & $0,35-5,39 \%$ & $0,35-5,39 \%$ \\
\hline Trans Fatty Acids & $0,04-0,08 \%$ & $0,04-0,08 \%$ \\
\hline Short Chain Fatty Acids & $0,35-0,44 \%$ & $0,35-0,44 \%$ \\
\hline Medium Chain Fatty Acids & $1,58-2,06 \%$ & $1,58-2,06 \%$ \\
\hline Long Chain Fatty Acids & $0,38-3,48 \%$ & $0,38-3,48 \%$ \\
\hline C:14_0* & $0,16-1,38 \%$ & $0,16-1,38 \%$ \\
\hline C:16_0* & $0,17-4,48 \%$ & $0,17-4,48 \%$ \\
\hline C: $18 \_0^{*}$ & $0,11-1,25 \%$ & $0,11-1,25 \%$ \\
\hline $\mathrm{C}: 18 \_1^{*}$ & $0,26-4,29 \%$ & $0,26-4,29 \%$ \\
\hline
\end{tabular}

Table 2: List of fatty acids analyzed by FTIR [2]

\section{Targeted models}

It is remarkable to say that FTIR technology permitted the creation of targeted model for the profile of pure milk, in order to avoid any adulterations with vegetable fats, melamine or cyanuric acid to show higher protein content, or water addition. This below mentioned curve (Figure 4), represents cow milk adulteration in Nederland. Y axis represents absorbance and X axis the wavelength.

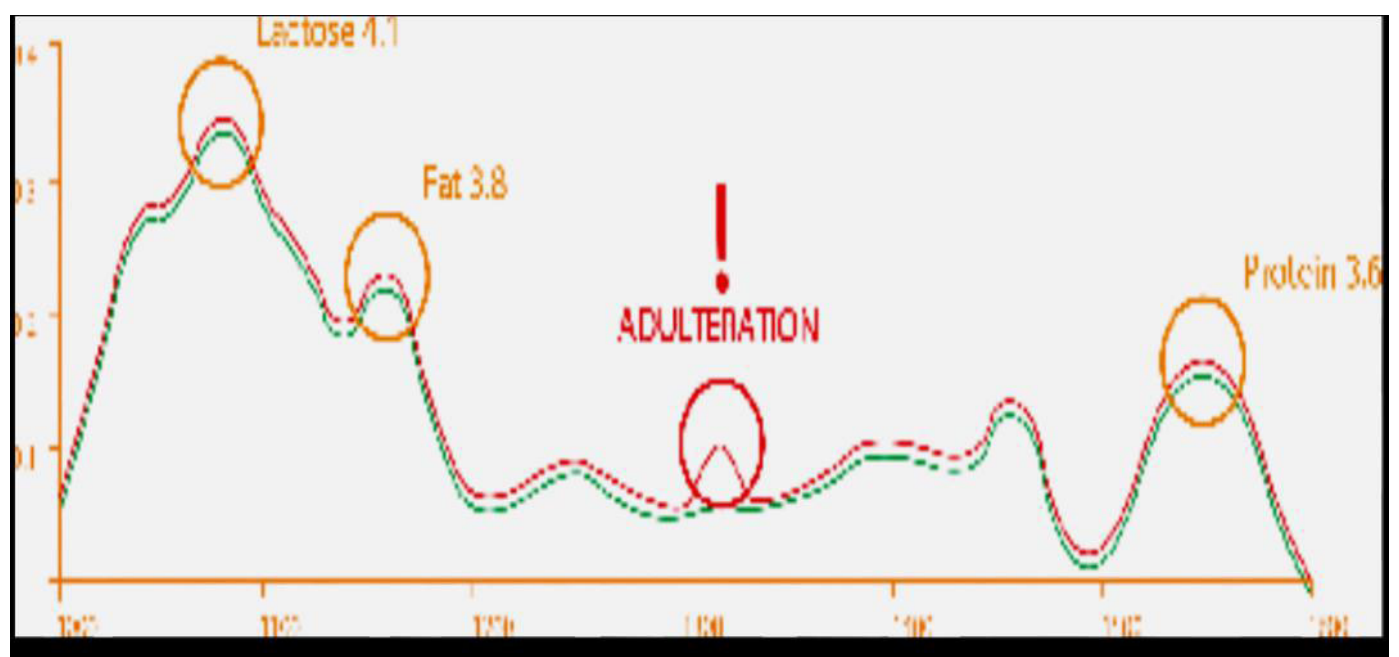

Figure 4: Adulteration predicting curve modeling [2] 


\section{Novel technologies for Somatic Cells Counting and for Individual Bacteria Counting}

\section{Somatic Cells Counting}

Somatic Cells counting were always a significant indicator for mastitis in milk for all mammal species. 30 years ago, several methods had been tried. Major importance was given to direct microscopic counting. The same path was followed for bacteria counting. Direct epifluorscent filter technique has developed further the microscopical observation. Quantitative measuring was done by Conductivity method. But the most successful routine method was the Fluoro-opto-electronic SCC counters, based on rotating disc method. Somatic cell's DNA was dyed with edithium bromide, emitting fluorescent to an electronic microscope by spraying the sample on the edge of a rotating disc. The light emitted was converted to electronic signal which in turn was interpreted in measuring numbers of somatic cells. The somatic cells counters were quite successful for sheep and goat milk with calibration of instruments with more than 1 million of somatic cells.

\section{For bacteria counting}

Bactoscan technique was used. Through different sample preparation, centrifugation for isolation of alive bacteria, dying the DNA of these bacteria with Acridine orange, counting was made with electronic microscope on the edge of a rotating disc. The Bactoscan technique was not applicable for sheep and goat milk for different reasons. For goat milk a high number of somatic cells fragments - produced during sample centrifugation - were affecting seriously the results turning in inaccuracies. For sheep milk, because of the high content of fat and protein, a new recipe for breaking down the protein micelles was required. It was something that changed totally the performance of the instrument.

After 2000, novel technology came out in the analytical testing market, with the Flow Cytometry. This methology was based on the principle of regulating a standard liquid stream carrying the somatic cells (Figure 5), or the individual bacteria both dyed with their respective fluorescent dye, passing through a standard cuvette permitting the pass of one somatic cell or individual bacteria (Figure 6). In both cases this technique was quite successful for all milk species. Especially for sheep and goat milk it was saving a serious cost of using the reference method of petri dish counting, but also permitted measuring of much more samples and produced results in the same day

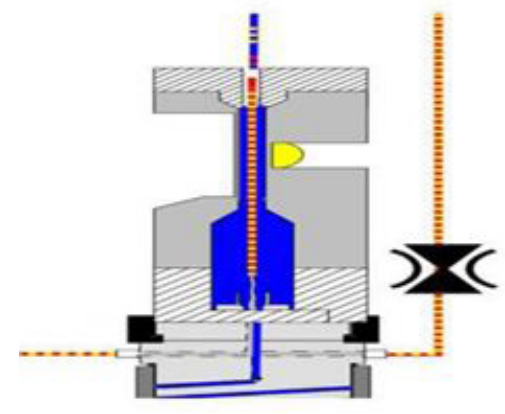

Figure 5: Flow Cytometry for SCC [3]

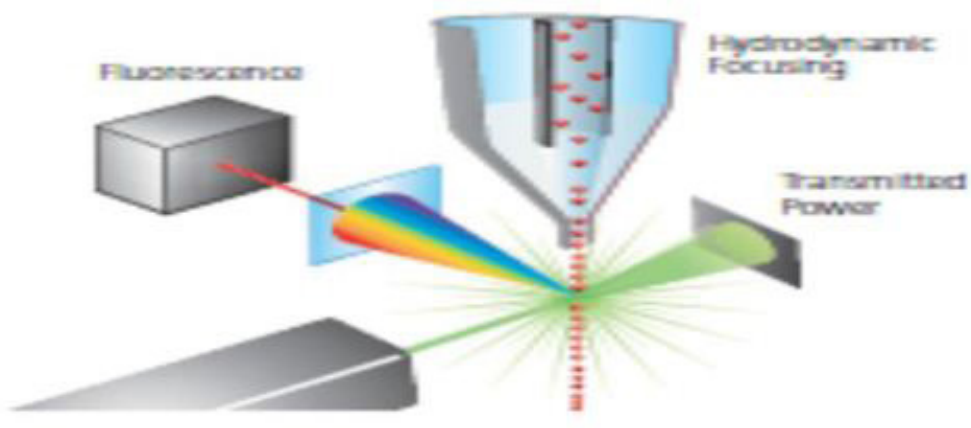

Figure 6: Flow Cytometry for Individual Bacteria Counting [4]

\section{Screening methods for antibiotics residues detection}

The importance of controlling the Hygiene of milk delivered to the processors remains in the first line of testing. Antibiotics residues in milk should be avoided by the milk producers. The Authorities engaged in controls, are seeking in effective methods for vigorous and reliable methods to prevent contaminations in the products processing lines. Today, ALL COMMERCIAL METHODS ARE AIMING IN MEETING THE MRLs of DIRECTIVE 96/23 EC for Residues of Harmful substances

$\checkmark$ The methods are classified in Qualitative and Quantitative

$\checkmark$ Choice of method depends on milk quantity and time limits

$\checkmark$ All methods are applied with same practice for all milk species

$\triangleright$ Confirmatory testings are required on positive results of 1 st screening

Here below, we present major firms in the market (Table 3).

The novel technology characteristic is the automation in processing and reading of results, adopted directly in the system of controlling data matched with other results of the producers. Here below we present major manufacturers' commercial instruments in the market (Figures 7,8,9 and 10). 


\begin{tabular}{|c|c|c|c|c|}
\hline Manufacturer & Name of test & Detection limits & $\begin{array}{c}\text { Analysis } \\
\text { time }\end{array}$ & Test method \\
\hline \multirow[t]{2}{*}{ AIM, Germany } & BRT & Betalactam, 2 ppb & $2,5 \mathrm{hrs}$ & Qualitative \\
\hline & *MCR3 & Betalactam, $<2 \mathrm{ppb}$ & $6 \mathrm{~min}$ & Quantitative \\
\hline \multirow[t]{2}{*}{ DSM, Netherlands } & Delvotest@Accelerator & Betalactam, 2 ppb, Tetracycline, 40 ppb & 1.5-2 hrs & Quantitative \\
\hline & Delvotest $\circledast$ BLF & Betalactam, 4 ppb & $5 \mathrm{~min}$ & Qualitative \\
\hline \multirow[t]{2}{*}{$\begin{array}{l}\text { Charm Science, } \\
\text { USA }\end{array}$} & Charm II & $\begin{array}{l}\text { Betalactam, } 4 \text { ppb, } \\
\text { Tetracycline, } 40 \text { ppb }\end{array}$ & $\begin{array}{l}\text { 8-10 min } \\
10-15 \mathrm{~min}\end{array}$ & Qualitative \\
\hline & Rosa Combo & Betalactam, 4 ppb, Tetracycline, 40 ppb & $2 \mathrm{~min}$ & Qualitative \\
\hline $\begin{array}{l}\text { IDEXX } \\
\text { Laboratories, USA }\end{array}$ & SNAP $\circledast$ & Betalactam, 4 ppb, Tetracycline, 50 ppb & $10 \mathrm{~min}$ & Qualitative \\
\hline \multirow[t]{2}{*}{ Neogen, USA } & Betastar $§$ & Betalactam, 4 ppb & $5 \mathrm{~min}$ & Qualitative \\
\hline & Betastar $\circledast$ Combo & Betalactam, 4 ppb, Tetracycline, 40 ppb & $5 \mathrm{~min}$ & Qualitative \\
\hline Unisensor, Belgium & TwinSensor & Betalactam, 4 ppb, Tetracycline, 40 ppb & $6 \mathrm{~min}$ & Qualitative \\
\hline
\end{tabular}

Table 3: Manufactures and test kits products with their performance

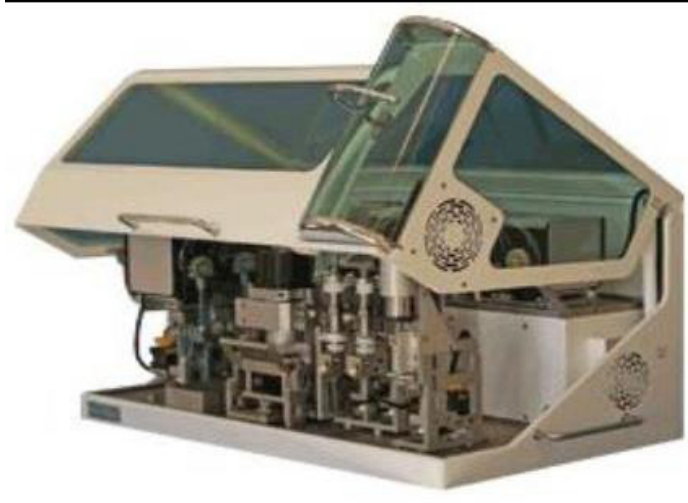

Figure 7: Firm: AIM, Model: MCR3

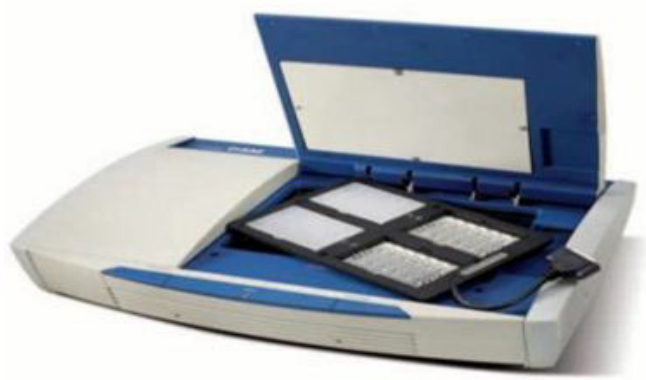

Figure 9: Firm: DSM, Model: Delvotest Accelerator

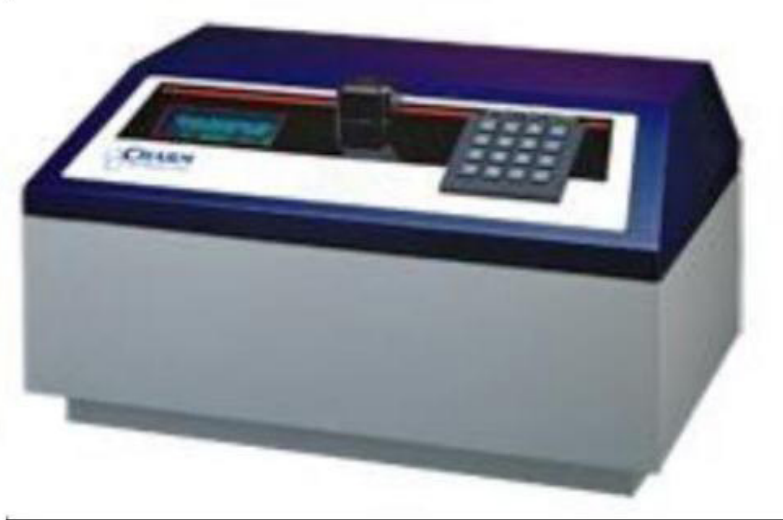

Figure 8: Firm: Charm Science, Model: Charm II

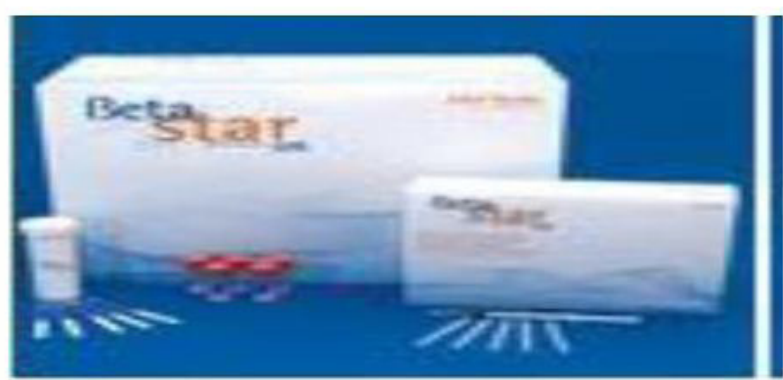

Figure 10: Firm: Neogen, Model: Betastar

\section{Milk adulteration and milk mixtures identification}

\section{Milk adulteration with water}

Milk adulteration with water was already mentioned in composition analysis, as one of the new routine parameters of Infrared Spectroscopy. As a reference method, it uses the Freezing Point in milk (FIL/IDF 108:2001). The equipment available in the market, is a completely automated apparatus thermistor cryoscope (Figure 11)

\section{Milk mixtures identification}

Milk mixtures identification was always an issue for testing since milk species have different value in fat and protein content. Several methods were established in bibliography. These methods are evaluated not only for their accuracy for the analyte, but also for their practical performance in the lab, the cost of analysis and the time required for definite result. Here below it is presented a 
Compendium of methods for milk mixtures (Table 4)

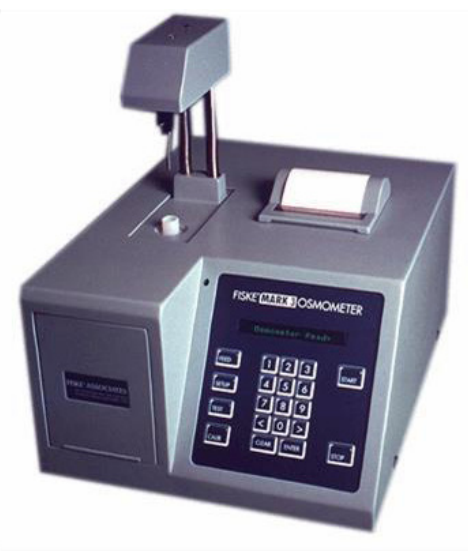

Figure 11: Fiske Thermistor cryoscope

\begin{tabular}{|c|c|c|c|c|c|}
\hline \multicolumn{6}{|c|}{ PHYSICOCHEMICAL METHODS } \\
\hline No & Analyte & Technique & Application field & Advantages & Disadvantages \\
\hline 1. & Fatty Acids & -TLC & $\begin{array}{c}\text {-Milk, Cheese } \\
\text { - (Cow in sheep- goat) }\end{array}$ & $\begin{array}{l}\text {-Small changes in fat } \\
\text { - Research method }\end{array}$ & $\begin{array}{l}\text {-Sensitivity } 10 \% \\
\text { - Not applied in defat- } \\
\text { ted products }\end{array}$ \\
\hline 2. & Triglycerides & $\begin{array}{l}\text {-GLC } \\
\text {-HPLC }\end{array}$ & $\begin{array}{c}\text {-Milk, Cheese } \\
\text { - (Cow in sheep- goat) }\end{array}$ & $\begin{array}{l}\text {-Almost rapid method } \\
\text { - Research method }\end{array}$ & $\begin{array}{l}\text {-Very expensive } \\
\text { - Experimental stage }\end{array}$ \\
\hline 3. & Caseins ( $a \varsigma 1)$ & $\begin{array}{l}\text { Ion exchange chroma- } \\
\text { tography FLPC }\end{array}$ & $\begin{array}{c}\text {-Milk, Cheese (2 } \\
\text { months old) } \\
\text { - (Cow in sheep- goat) }\end{array}$ & $\begin{array}{l}\text {-Almost rapid method } \\
\text { - Research method }\end{array}$ & $\begin{array}{l}\text {-Very expensive } \\
\text {-Expertise personnel }\end{array}$ \\
\hline 4. & $\begin{array}{l}\text {-Peptides } \\
\text {-Aminoacids } \\
\text {-Whey proteins }\end{array}$ & $\begin{array}{c}\text {-HPLC } \\
\text {-RP HPLC } \\
\text {-GLC }\end{array}$ & $\begin{array}{l}\text {-Various dairy products } \\
\text { - (Cow in sheep- goat) }\end{array}$ & $\begin{array}{l}\text {-Almost rapid method } \\
\text { - Research method } \\
\text {-Very sensitive } 0.1 \%\end{array}$ & $\begin{array}{l}\text { - Very expensive } \\
\text { - Very complicate in } \\
\text { sample preparation }\end{array}$ \\
\hline \multicolumn{6}{|c|}{ ELECTROPHORETIC METHODS } \\
\hline 1. & Caseins ( $a \varsigma 1)$ & PAGE & $\begin{array}{c}\text {-Milk, Yogurt } \\
\text { - (Cow in sheep- goat) }\end{array}$ & $\begin{array}{c}\text {-Sensitivity } 1 \% \\
\text {-Moderate cost } \\
\text {-Recognized on } \\
\text { National scale various } \\
\text { European countries }\end{array}$ & $\begin{array}{l}\text { - Poor quantitative } \\
\text { accuracy } \\
\text { - Very complicate in } \\
\text { sample preparation }\end{array}$ \\
\hline 2. & Caseins $(\alpha \varsigma 1)$ & $\begin{array}{l}\text { Electrophoresis on } \\
\text { Acetic Cellulose }\end{array}$ & $\begin{array}{c}\text {-Milk, Yogurt } \\
\text { - (Cow in sheep- goat) }\end{array}$ & & $\begin{array}{c}\text { Poor sensitivity over } \\
\text { than } 10 \%\end{array}$ \\
\hline 3. & Para- $\kappa$-casein & PAGE & $\begin{array}{c}\text { - Cheese } \\
\text { - (Cow in sheep- goat) }\end{array}$ & Moderate cost & $\begin{array}{l}\text { - Poor sensitivity } \\
\text { - Very complicate in } \\
\text { sample preparation } \\
\text { - Very slow method } \\
\text { Expertise personnel }\end{array}$ \\
\hline 4. & $\gamma_{1,2}$-casein & IEF & $\begin{array}{c}\text {-Milk, Cheese } \\
\text {-(Cow in sheep- goat) }\end{array}$ & $\begin{array}{l}\text {-EU reference method } \\
\text {-Sensitivity } 1 \%\end{array}$ & $\begin{array}{l}\text { - Very complicate in } \\
\text { sample preparation } \\
\text {-Very slow method } \\
\text {-Expertise personnel }\end{array}$ \\
\hline 5. & $\gamma_{1,2}$-casein & IEF & $\begin{array}{l}\text {-Milk, Cheese } \\
\text {-(Goat in sheep) }\end{array}$ & -Sensitivity $1 \%$ & $\begin{array}{l}\text { - Poor quantitative } \\
\text { accuracy } \\
\text { - Very complicate in } \\
\text { sample preparation } \\
\text { - Very slow method } \\
\text { - Expertise personne } \\
\text {-Not recognized }\end{array}$ \\
\hline 6. & $\begin{array}{l}\text { Whey proteins } \\
\text { ( } \beta \text {-lactoglobulin) }\end{array}$ & PAGE & $\begin{array}{c}\text {-Milk, Fresh } \\
\text { Cheese } \\
\text {-(Cow in sheep- goat) }\end{array}$ & $\begin{array}{l}\text {-Moderate cost } \\
\text { - Sensitivity } 1-2 \%\end{array}$ & $\begin{array}{c}\text { - Complicate in sample } \\
\text { preparation } \\
\text { - Poor accuracy with } \\
\text { heated samples }\end{array}$ \\
\hline 7. & $\begin{array}{l}\text { Whey proteins } \\
\text { ( } \beta \text {-lactoglobulin) }\end{array}$ & $\mathrm{CZE}$ & $\begin{array}{c}\text {-Milk, Cheese } \\
\text {-(Mixtures of cow, goat } \\
\text { and sheep milk) }\end{array}$ & $\begin{array}{l}\text {-Rapid method } \\
\text {-Sensitivity 1-5\% } \\
\text {-Moderate cost } \\
\text {-Good accuracy 2-5\% }\end{array}$ & $\begin{array}{l}\text {-Expensive equipment } \\
\text { - At experimental stage }\end{array}$ \\
\hline
\end{tabular}




\begin{tabular}{|c|c|c|c|c|c|}
\hline \multicolumn{6}{|c|}{ ELECTROPHORETIC METHODS } \\
\hline No & Analyte & Technique & Application field & Advantages & Disadvantages \\
\hline 8. & $\begin{array}{l}\text { Whey proteins } \\
\text { ( } \beta \text {-lactoglobulin) }\end{array}$ & IEF & $\begin{array}{c}\text { - Milk, Cheese } \\
\text { - (Cow in sheep- goat) } \\
\text {-(Goat in sheep) }\end{array}$ & -Sensitivity $0.5-3 \%$ & $\begin{array}{l}\text {-Expensive equipment } \\
\text {-At experimental stage } \\
\text { - Expertise personnel }\end{array}$ \\
\hline 9. & Para-k-casein & CZE & $\begin{array}{l}\text { - Milk, Cheese } \\
\text { - (Goat in sheep) }\end{array}$ & $\begin{array}{l}\text {-Sensitivity 1\% } \\
\text {-Accuracy 1-2.6\% }\end{array}$ & $\begin{array}{l}\text {-Expensive equipment } \\
\text {-At experimental stage } \\
\text { - Expertise personnel }\end{array}$ \\
\hline 10. & Caseins ( $\alpha \varsigma 1)$ & CZE & $\begin{array}{c}\text { - Milk, Cheese } \\
\text { - (Cow in sheep- goat) }\end{array}$ & $\begin{array}{l}\text {-Sensitivity } 1 \% \\
\text {-Accuracy }<5 \%\end{array}$ & $\begin{array}{l}\text {-Expensive equipment } \\
\text {-At experimental stage } \\
\text {-Expertise personnel }\end{array}$ \\
\hline \multicolumn{6}{|c|}{ IMMUNOLOGICAL, IMMUNOELECTROPHORETIC METHODS } \\
\hline 1. & Immunodiffusion & On immunoglobulins & $\begin{array}{l}\text {-Milk, Cheese } \\
\text {-(Mixtures of cow, goat } \\
\text { and sheep milk) }\end{array}$ & $\begin{array}{l}\text { - Very simple in ap- } \\
\text { plication } \\
\text { - Sensitivity 1-2.5\% } \\
\text { - Low cost of equip- } \\
\text { ment } \\
\text { - Recognized in } \\
\text { France }\end{array}$ & $\begin{array}{l}\text { - Very expensive in } \\
\text { reagents / sample } \\
\text { - Very poor quantitative } \\
\text { accuracy especially in } \\
\text { the presence of colos- } \\
\text { trum or with heated } \\
\text { samples }\end{array}$ \\
\hline 2. & $\begin{array}{l}\text { Dual Radial } \\
\text { Immunodiffusion }\end{array}$ & On immunoglobulins & $\begin{array}{l}\text {-Milk, Cheese } \\
\text {-(Mixtures of cow, goat } \\
\text { and sheep milk) }\end{array}$ & $\begin{array}{l}\text { - Very simple in ap- } \\
\text { plication } \\
\text { - Sensitivity } 1-4 \% \\
\text { - Low cost of equip- } \\
\text { ment } \\
\text { - Recognized in } \\
\text { France }\end{array}$ & $\begin{array}{l}\text { - Very expensive in } \\
\text { reagents /sample } \\
\text { - Better quantitative } \\
\text { accuracy but over } 20 \% \\
\text { mixtures is CV }>15 \%\end{array}$ \\
\hline 3. & $\begin{array}{c}\text { Rocket } \\
\text { Immunoelectrophoresis }\end{array}$ & $\begin{array}{l}\text { Antiserum from } \\
\text { goats for cow's milk }\end{array}$ & $\begin{array}{l}\text {-Milk, Cheese } \\
\text {-(Mixtures of cow, goat } \\
\text { and sheep milk) }\end{array}$ & - Sensitivity $1-5 \%$ & $\begin{array}{l}\text {-Limited application } \\
\text { and recognition }\end{array}$ \\
\hline 4. & $\begin{array}{c}\text { Crossed } \\
\text { Immunoelectrophoresis }\end{array}$ & $\begin{array}{l}\text { Antiserum from rabbit } \\
\text { for cow's whey proteins }\end{array}$ & $\begin{array}{l}\text { Limited application on } \\
\text { blue cheeses }\end{array}$ & $\begin{array}{l}\text { - Sensitivity } 0.1-2 \% \\
\text { - Not affected by heat } \\
\text { treatment } \\
\text {-Recognized in France }\end{array}$ & $\begin{array}{l}\text {-Limited application } \\
\text { - Unknown accuracy, } \\
\text { cost, or accuracy }\end{array}$ \\
\hline 5. & Counter - current & $\begin{array}{l}\text { Antiserum from rabbit } \\
\text { for cow's whey proteins }\end{array}$ & $\begin{array}{l}\text {-Milk, Cheese } \\
\text {-(Mixtures of cow, goat } \\
\text { and sheep milk) }\end{array}$ & - Sensitivity $0.1-2 \%$ & $\begin{array}{l}\text {-Very poor accuracy } \\
\text {-Not applied in heat } \\
\text { treated products or with } \\
\text { developed proteolysis }\end{array}$ \\
\hline 6. & $\begin{array}{l}\text { Immunodotting tech- } \\
\text { nique }\end{array}$ & $\begin{array}{l}\text { Antiserum from rabbit } \\
\text { for cow's whey proteins }\end{array}$ & $\begin{array}{l}\text {-Milk, Cheese } \\
\text {-(Mixtures of cow, goat } \\
\text { and sheep milk) }\end{array}$ & $\begin{array}{l}\text { - Sensitivity } 0.1-2 \% \\
\text { - Not affected by heat } \\
\text { treatment }\end{array}$ & Very poor accuracy \\
\hline 7. & ELISA & $\begin{array}{l}\text { Polyclonic antibodies } \\
\text { for cow/goat immuno- } \\
\text { globulins }\end{array}$ & $\begin{array}{l}\text {-Milk, Cheese } \\
\text {-(Mixtures of cow, goat } \\
\text { and sheep milk) }\end{array}$ & $\begin{array}{c}\text {-Sensitivity } 0.1-1 \% \\
\text {-Rapid method } \\
\text {-Easy application } \\
\text {-Cheap equipment } \\
\text {-Recognized in Ger- } \\
\text { many }\end{array}$ & $\begin{array}{l}\text {-Poor quantitative } \\
\text { accuracy/ Can be } \\
\text { characterized as semi } \\
\text { quantitative } \\
\text { - Expensive in reagents/ } \\
\text { High cost per sample }\end{array}$ \\
\hline
\end{tabular}

Table 4: A Compendium of methods for Milk Mixtures Detection [6]

In last 15 years, almost 80 papers markers of cow's milk and methods used in the detection have been published. (Table 5)

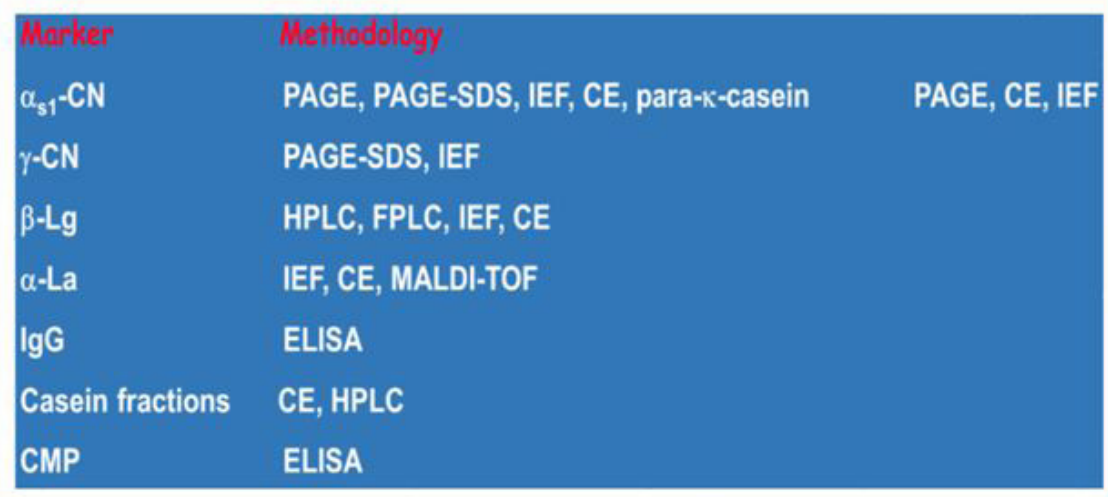

Table 5: Marker and methods [5] 
The Commission Decision 93/256/EEC has stated that "Methods based only on chromatographic analysis (or other descriptive techniques) without use of molecular spectrometric detection are not suitable for use as confirmatory methods". This official position has encouraged development of mass spectrometry (MS)- based methods

\section{Authenticity of sheep and goat PDO products}

Protected Demographic Origin (PDO) products are remaining as a very valuable asset for the Sheep and Goat Dairy Sector. Since these products are very popular especially in their original place of production and usually are targeted by cow milk processors to copy them, the specific characteristics that prescribe the particular character of these products are listed below:

D Characteristics of Raw Milk Used for Cheese Making: Specific cultures used, or Eco flora isolated in product, milk specie, composition of non-adulterated raw product, animal breed, local vegetation, specific aromatic compounds, trace elements and metals

$\checkmark$ Clotting Enzymes: Natural rennet from young animals, artificial preparation enzymes etc.

$\checkmark$ Processing Practices: Particular techniques applied in product manufacturing

$\checkmark$ Ripening Process for Cheese: Salting process, temperature used, ripening time.

$\checkmark$ Character of Cheese: Soft-semi hard- hard cheese - Characteristic peptides, amino acids in hard cheese

$\checkmark$ Characteristic Texture: Holes in the cheese, elasticity of cheese...

$\checkmark$ Flavor and Aroma: Connected to specific aromatic compounds resulted from ripening process

Many analytical methods are involved, very often in two or three combination to verify specific analyte[5]:

$\triangleright$ Electrophoresis - gel (WP, C)

$\checkmark$ Capillary electrophoresis

$\checkmark$ Chromatographic methods RP-HPLC (WP, C)

$\checkmark$ Immunological methods (WP, C)

$\checkmark$ Polymerase Chain Reaction (somatic cell's DNA)

$\checkmark$ Electronic Nose Aroma Detector

\section{Conclusions}

We are already in a new era of testing technology. Many obstacles in the sector of sheep and goat dairy sector have been removed. An enormous number of scientific reports in several subsectors i.e. nutrition, genetics, dairy products technology, have revealed superiority of sheep \& goats milk ingredients. Novel technology in analytical testing is to help producers' associations for further improvement of their raw material. On the other hand, the challenge remains in hand of processors to respond to consumers demand for biological products.

\section{List of References}

1. Beheregaray LB, Gibbs JP, Havill N, Fritts TH, Powell JR, et al. (2004) Giant tortoises are not so slow : Rapid diversification and biogeographic consensus in the Galápagos. PNAS 101: 6514-9.

2. Foss (2003) Manual on FTIR instrument FT plus authenticity curve.

3. Foss (2003) Manual on Somatic Cells Counter Leaflet.

4. Bentley Manual on IBC Bacteria counters Manual

5. Detection of Species Adulteration in Milk and Dairy Products - Key Note presentation by Francesco Addeo- Sardinia 2007 Alghero - Italy

6. A Compendium of methods for Milk Mixtures Detection - By George Psathas CMIO internal report 2000

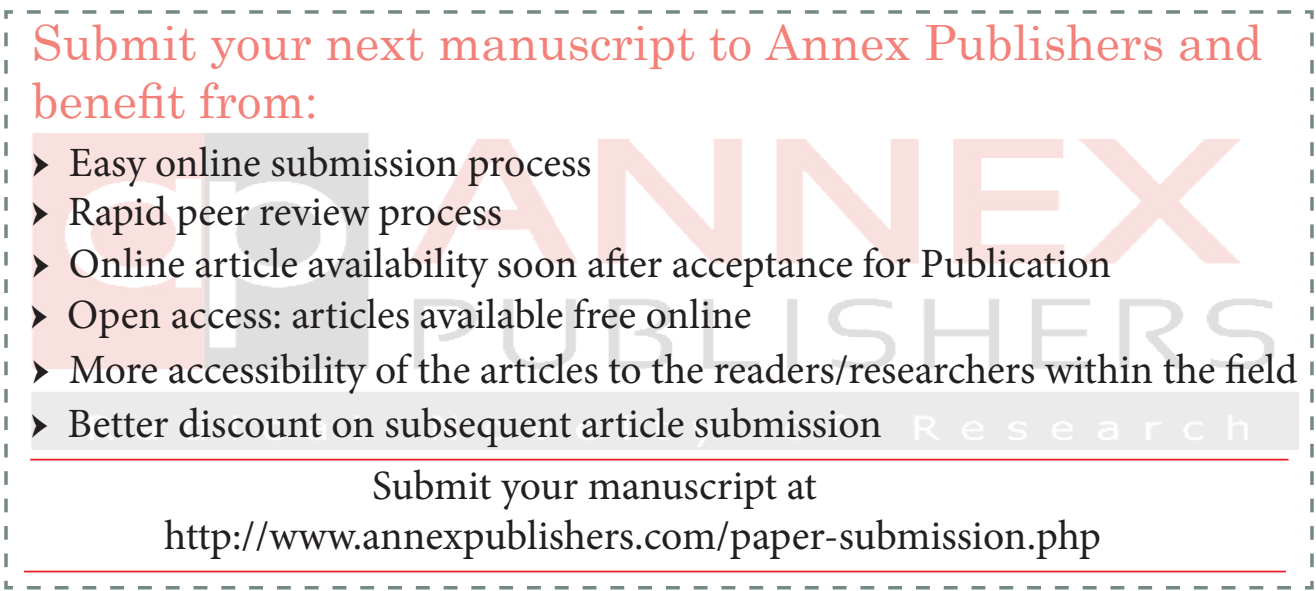

